\title{
高令者の大腿骨遠位部骨折の治療
}

\author{
済生会江津総合病院整形外科 \\ 村 田 雅 明・松 井 美 房

\section{Treatment of Distal Femoral Fracture for Old Patients} \\ by \\ Masaaki Murata and Yosifusa Matsui \\ Department of Orthopaedic Surgery, \\ Saiseikai Gotsu General Hospital
}

\begin{abstract}
Osteosynthes is by percutaneus intramedullary nailing using multiple pinning of $\mathrm{K}$-wires or rush pins were performed for six patients above 65 years old who sustained distal femoral fracture. Four of them acquired good and early bony union. Two of them acquired good range of motion of the knee.

Advantages of these methods for old patients are as follows.

First, the invasion of these methods is little for the femoral condyles that are fragile due to osteoporosis. Second, the invasion of these methods for muscles around the knee joint is little. Third, it is easy even for old patients to acquire early bony union, because there is no invasion on the periosteal membrane by these methods. Forth, required time for these operations is short and bleeding is a little.

Therefore, these methods are very useful for distal femoral fracture for old patients whose range of activity is less than that of young people.
\end{abstract}

目的

最近の高令化社会の中でわれわれ整形外科医にとつ て，高令者の骨折の治療はしばしば問題となる．今回 われわれは 65 才以上の大腿骨遠位部骨折 6 例を治療す る機会を得たので報告する。

\section{症例}

66 才から 99 才までの平均 76.5 才, 男 1 例女 5 例の 計 6 例で，合併外傷は同側の大腿骨骨幹部骨折 1 例, 頭部打撲・左第 5 指基節骨骨折 1 例であった。糖尿病 を伴うもの 1 例, RA を伴うもの 1 例で, プレドニン内 服中であった。また 1 例は受傷の 7 年前に今回の大腿 骨遠位部骨折と同側に化膿性関節炎のため，他院にて TKRを受けていた。

受傷機転としては，歩行中などに膝をついて転倒す るというような軽微なものが 4 例で，合併外傷のある 2 例はそれぞれ木材の落下, 交通事故と大きな外力が
加わっている.

受傷時のX 線像では, 部位は顆上部が 5 例, 顆部か ら顆上部にいたるものが 1 例であった。骨折の型は螺 旋骨折 3 例, 斜骨折 2 例 (このうち 1 例は粉砕型), 横 骨折 1 例であった。関節内骨折は 1 例にのみ認めた.

\section{治療}

当院入院後全例鋼線牽引を施行し, その後全例に手 術を行った。手術は rush pin 2 本，または k-wire 4 から 5 本を大腿骨内・外顆より骨髄内に刺入するもの で (以下 rush pin 法, k-wire multiple pinning 法), それぞれ 2 例と 4 例に行った。麻酔は全麻・腰麻・硬 麻がそれぞれ 2 例づつ, 平均手術時間は 37.5 分であっ た。術後は約 10 週の外固定 (ギプスまたは坐骨結節支 持長下肢装具) で, 起立開始は平均 5 週であった。

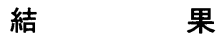

$\mathrm{X}$ 線像では 4 例に良好な骨癒合を得， 1 例は偽関節 


\begin{tabular}{|c|c|c|c|c|c|c|c|c|}
\hline & & AGE & SEX & 受傷機転 & 治 療 & 骨 凂 合 & 可 動 域 & 術後歩行 \\
\hline 症 例 1 & 1 & 70 & 女 & 歩 行 中 転 倒 & K-wire & 良 好 & 良 好 & 独立步行可 \\
\hline 症 例 2 & 2 & 69 & 女 & 交 通 事 故 & rush pin & 良 好 & 良 好 & 独立歩行可 \\
\hline 症 例 3 & 3 & 87 & 女 & 室内で転 倒 & K-wire & 良 好 & 不 良 & 杖 歩 行 可 \\
\hline 症 例 4 & 4 & 99 & 女 & 室 内で転 倒 & K-wire & 不 明 & 不 良 & 歩＼cjkstart行 \\
\hline 症 例 5 & 5 & 68 & 女 & 入浴中転倒 & rush pin & 不 良 & 不 良 & 行 器 \\
\hline 症 例 6 & 6 & 66 & 男 & 材木の落下 & K-wire & 良 好 & 不 良 & 独立歩行可 \\
\hline
\end{tabular}

${ }^{*} \mathrm{~K}$-wire $\cdots \cdots \cdot \mathrm{K}$-wire multiple pinning 法

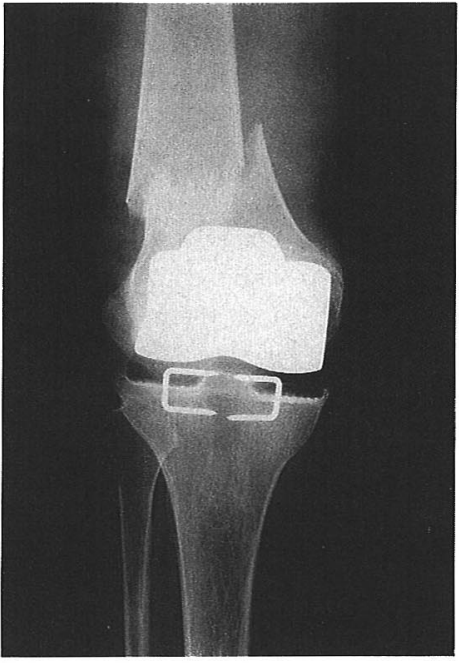

図 1 症例 1

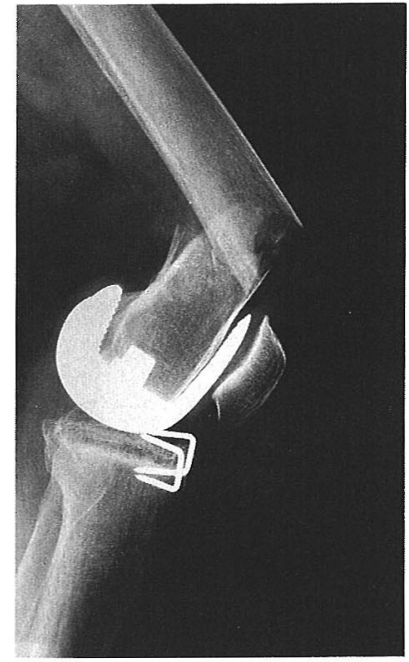

受傷時

4 力月の時点で骨癒合良好, 独立歩行可能で可動域も 屈曲 $100^{\circ}$ 以上（図 3 )。

症例 $2: 69$ 才，女性（図 4)。

S 5810 月, 交通事故で受傷。頭部打撲, 左第 5 指 基節骨骨折を合併. 約 2 週鉱線牽引後, 腰麻下でイメ ージ下に内外顆より rush pinを 1 本づつ挿入. 術後 4 週で仮骨形成を認める。術後ギプス固定 8 週. 術後 5 週で軽荷重, 10 週で全荷重. 術後約 9 力月の時点で骨 瘾合良好, 独立歩行可能で可動域も屈曲 $100^{\circ}$ 以上。 症例 $3: 87$ 才，女性（図 5).

S 6212 月,室内で転倒し受傷. 5 日間鋼線率引後, 硬麻下でイメージ下に内外顆よりそれぞれ k-wire 2 本 づつ挿入. 術後約 4 週のギプス固定の後, 座骨結節支 持の長下肢装具到着. 術後 4 週より軽荷重. 術後 5 週 

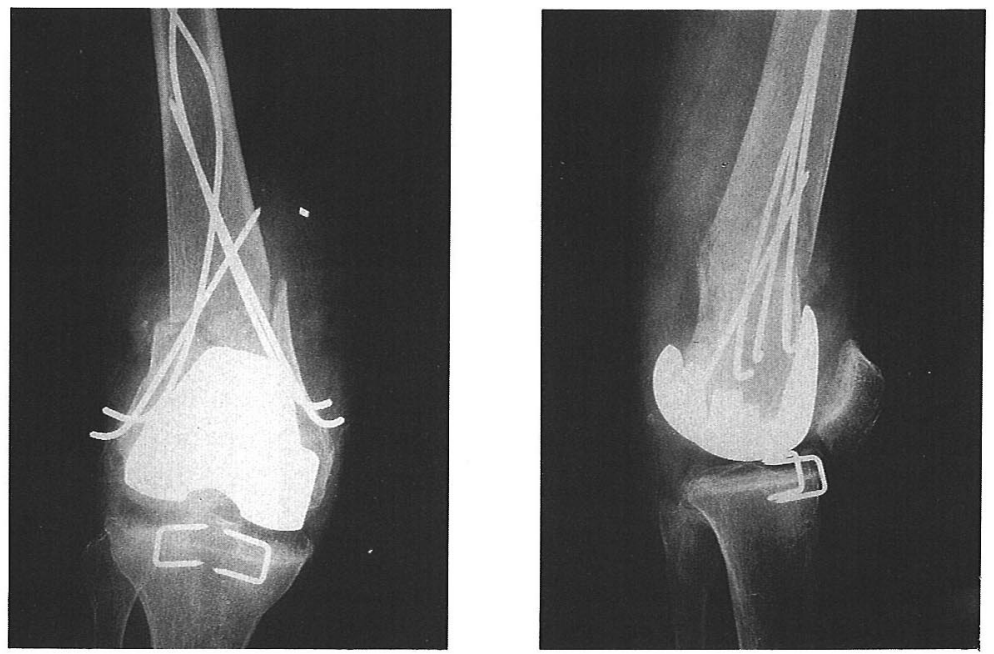

図 2 症例 1 術直後 $\mathrm{k}$-wire multiple pinning 法

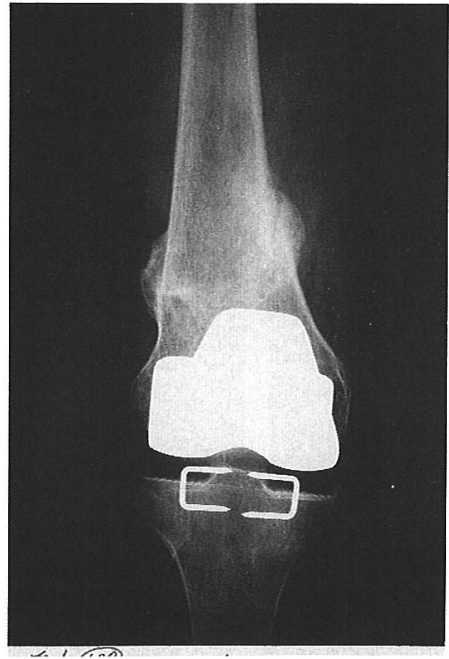

図 3 症例 1

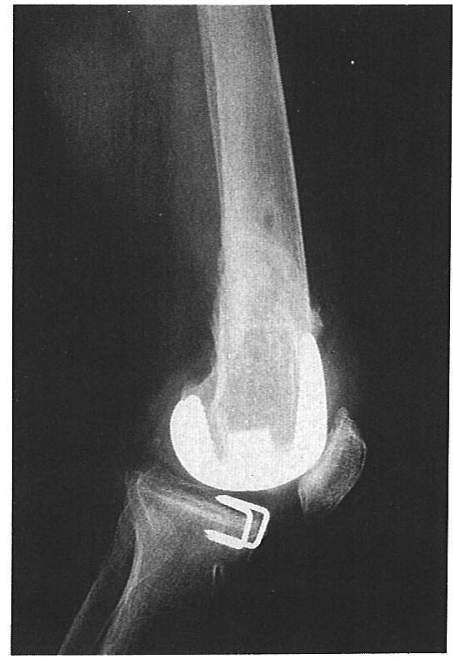

術後約 4 力月
で仮骨形成を認める。術後約 5 力月の時点で骨瘱合良 好，杖歩行可能であるが可動域は $-20^{\circ}$ から $60^{\circ}$ 。

$$
\text { 考察 }
$$

大腿骨遠位部は大腿骨脛部・橈骨末端・脊椎椎体と ともに海綿骨が多く，骨粗鬆症を伴うような高令者で はわれわれの症例のごとく, 軽微な外力で骨折し得る ${ }^{1)}$. 今回われわれは高令者に対し，保存的治療と比して卧 床期間の短縮と早期 ADL 回復を目的とし rush pin
法, k-wire multiple pinning 法による手術を行った。 若年者の大腿骨遠位部骨折に対してわれわれは，フッ ク・プレート,コンダイル・プレートなどを用いるが2)3， 高令者に対しては骨粗秐症により脆弱化した大腿骨顆 部への侵襲が大きいこと, 筋力の低下している高令者 に対して，膝周囲の筋肉に対する侵襲が大きいことよ りこれらの方法は行わなかった。 rush pin 法, k-wire multiple pinning 法ではこれらの侵襲はきわめて小さ い. 今回の治療経験よりさらにこれらの方法では, 骨 


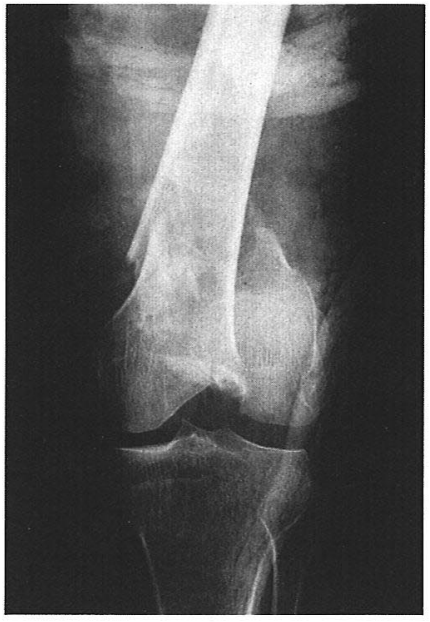

来院時

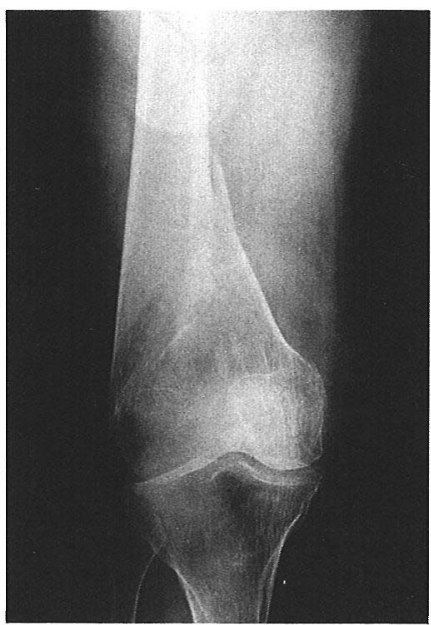

受傷時

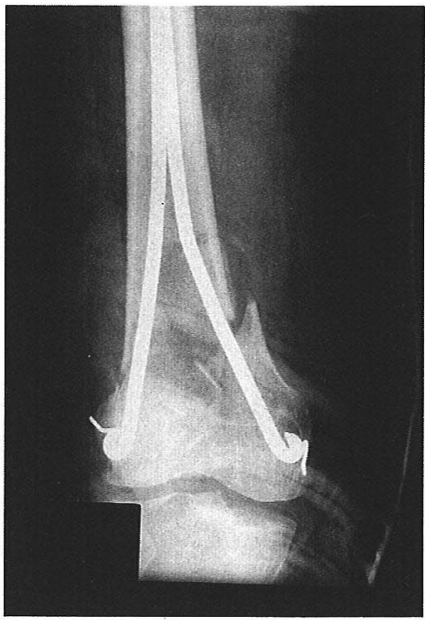

術直後

図 4 症例 2 rush pin 法

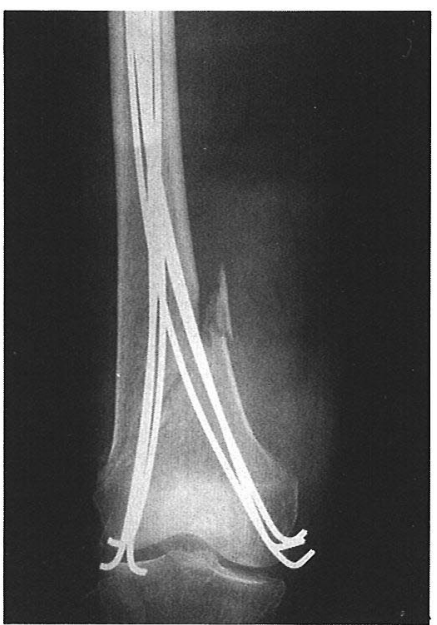

術直後

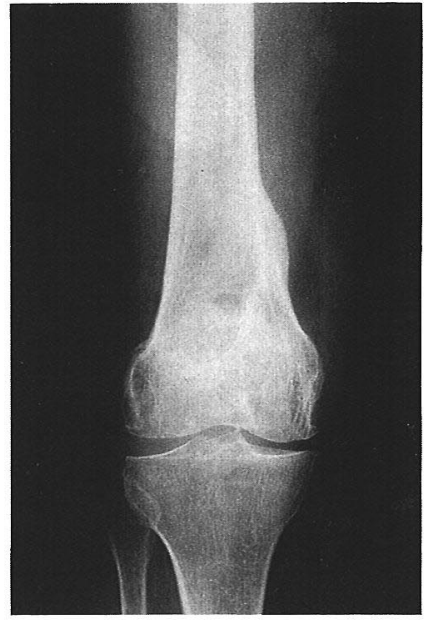

術後約 9 力月

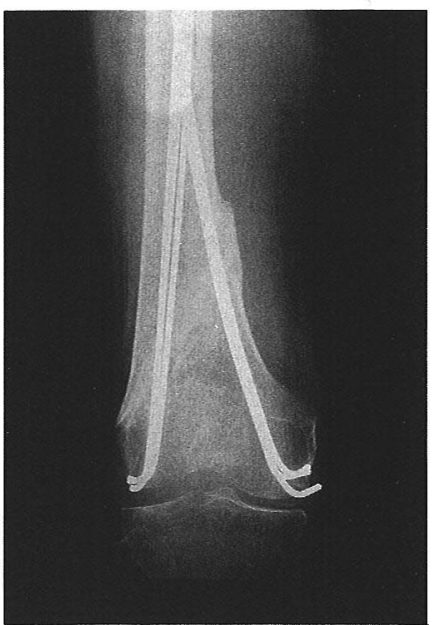

術後 5 力月

図 5 症例 3 k-wire multiple pinning 法

膜に侵襲を加えないために骨痖合を早期に得ることが 出来, 手術時間も短く出血も少ない. 欠点としては上 記のプレートに比べて固定力が劣り, 直視下手術でな いため完全な整復が困難である。しかし高令者では若 年者に比べて活動性が小さく，これらの欠点はさほど 重要ではないと考える。したがって高令者の大腿骨遠 位部骨折に対して, rush pin 法, k-wire multiple pinning 法による治療は非常に有意義なものと考える.
総

括

1. 65 才以上の高令者の大腿骨遠位部骨折 6 例に対 $し て$, rush pin 法, k-wire multiple pinning 法による 治療を行った。

2.4 例に良好な骨澸合を得，2 例は可動域も良好 であった。ADLはほぼ受傷前と変わらなかった。

3. 大腿骨遠位部骨折に対するこれらの方法は，侵 襲の小さいこと，骨瘾合が早期に得られることより， 
高令者には非常に有効な方法と考えられる。

$$
\text { 参考 文 献 }
$$

1）岩瀬秀明 : 大腿骨下端部顆上顆部骨折の受傷機転に 関する実験的研究. 整形外科バイオメカニクス, $7: 191$
$-198,1985$.

2）大野正昭: 大腿骨顆部, 顆上骨折の検討. 日本災害医 学会会誌, $30: 787-790,1982$.

3）西島雄一郎 : 大腿骨顆部, 顆上骨折の検討. 中部整災 誌, $29: 1623-1624,1986$. 